\title{
PRELIMINARY PHYTOCHEMICAL SCREENING, CHARACTERIZATION, AND ANTIDIABETIC ACTIVITY OF LEAF EXTRACT OF CANNA INDICA L. IN STREPTOZOTOCIN-INDUCED DIABETIC MODEL
}

\author{
PRASHANT KUMAR YADAV*, SISODIA SS \\ Department of Pharmacy, Faculty of Pharmacy, Bhupal Nobles University, Udaipur, Rajasthan, India. Email: prashant.8266@gmail.com
} Received: 17 November 2019, Revised and Accepted: 11 December 2019

\section{ABSTRACT}

Objective: This study aimed to evaluate the antidiabetic effects of the leaf extract of Canna indica L. in streptozotocin (STZ)-induced diabetic model. The present investigation indicated that the leaf of $C$. indica L. possessed significant antihyperglycemic potential which may prove the claimed use of the plant in amelioration of diabetes.

Methods: Male Swiss albino mice fasted for $12-14 \mathrm{~h}$ and weights were recorded prior to the induction of diabetes. Experimental diabetes was induced by a single intraperitoneal injection of $150 \mathrm{mg} / \mathrm{kg}$ of STZ, freshly dissolved in $0.1 \mathrm{M}$ citrate buffer $(\mathrm{pH}=4.5)$. Then, the solution was immediately administered intraperitoneally to each mouse. Thirty minutes after the injection, the mice were allowed free access to food and water. After $6 \mathrm{~h}$ STZ injection, mice were given a 5\% dextrose solution for the next $24 \mathrm{~h}$. The development of diabetes was confirmed after 3 days of the STZ injection and mice with fasting blood glucose level (BGL) $>200 \mathrm{mg} / \mathrm{dl}$ were considered as diabetic and were selected for the experiments. After successfully developing the diabetes animals were divided into six groups and each group contains six mice. Group I: Normal control mice administered vehicle only; Group II: Diabetic control mice administered vehicle only; Group III: Tested mice administered glibenclamide $5 \mathrm{mg} / \mathrm{kg}$; and Group IV-VI: Tested mice administered C. indica L. at doses of 100, 200, and $400 \mathrm{mg} / \mathrm{kg}$, respectively. All groups received treatments once daily for 14 days. The fasting BGL and body weight were determined at $0,7^{\text {th }}$, and $14^{\text {th }}$ days.

Results: The effect of $C$. indica L. on BGL having significant $(\mathrm{p}<0.05$ and $\mathrm{p}<0.001)$ reduction in BGL starting $1 \mathrm{~h}$ when compared to the negative control. Administration of glucose $(2 \mathrm{~g} / \mathrm{kg})$ to the mice produced significant $(\mathrm{p}<0.001)$ increase in BGL $30 \mathrm{~min}$ following $1 \mathrm{~h}$ after glucose loading, confirming the induction of hyperglycemia. The extract with three doses $(100,200$, and $400 \mathrm{mg} / \mathrm{kg}$ ) showed a significant reduction in BGL. The phytochemical screening of the leaves extract was done for the presence of alkaloid, saponin, terpene, carbohydrate, steroid, protein, cholesterol, flavonoids. Amino acid was absent in $C$. indica L. leaves.

Conclusion: It is concluded from this study that the alcohol extracts of $C$. indica L. leaves possess significant antihyperglycemic effects.

Keywords: Canna indica L., Physicochemical, Phytochemical, Antihyperglycemic.

(c) 2020 The Authors. Published by Innovare Academic Sciences Pvt Ltd. This is an open access article under the CC BY license (http://creativecommons. org/licenses/by/4. 0/) DOI: http://dx.doi.org/10.22159/ajpcr.2020.v13i2.36396

\section{INTRODUCTION}

Diabetes mellitus (DM) is a chronic metabolic disorder manifested in the form of hyperglycemia as a consequence of defect in insulin secretion and/or insulin action along with an imbalance in the metabolism of carbohydrates, fats, and proteins. The incidence of DM has reached epidemic proportions predominantly due to changes in lifestyle and increase in the prevalence of obesity, cystic fibrosis, and mitochondrial defects [1]. Maintenance of normal blood glucose levels (BGLs) is essential in diabetes since a decrease in BGLs (hypoglycemia) or increase in BGLs (hyperglycemia) is unwanted phenomenon. Hence, monitoring of antidiabetic drug therapy in the presence of other drugs is very much needed to maintain the safety [2]. There is an explosive boost in diabetic patients for the last two decades and is expected to be the seventh major cause of death by 2030 [3]. Further, it occupies the third position when its fatal complications are considered [4]. DM is characterized by several complications, basically chronic hyperglycemia with altered metabolism of carbohydrate, fat, and protein, which results from fault insulin secretion, inefficient insulin action, or both [5]. Such deficiency results in damage of many-body systems, in particular, the blood vessels and nerves. Diabetes has negative impact on modern lifestyle with direct consequence of increased overweight and sedentary population [6]. The epidemiological status of diabetes has stimulated the researchers for new innovations and targets for the eradication of this incurable disease. Search for safer and effective hypoglycemic agents is a continuous challenge in managing diabetes [7].

Canna (or canna lily, although not a true lily) is a genus of nineteen species of flowering plants. The closest living relations to cannas are the other plant families of the order Zingiberaceae (gingers), Musaceae (bananas), Marantaceae, Heliconiaceae, Strelitziaceae, etc. [8]. Canna is the only genus in the family Cannaceae. Such a family has almost universally been recognized by taxonomists [9]. Canna indica Linn. is commonly known as Indian shot or Canna lily. It is widely used for removal of organic pollutants, nitrogen, phosphorous, and heavy metals [10]. Root decoction is used for the treatment of fever, dropsy, and dyspepsia [11]. Seed juice is used to relieve earaches. The leaves of C. indica showed antimicrobial activity and analgesic activity, and the rhizomes showed a good anthelmintic activity $[12,13]$. In this study, we investigated the effect of leaf extract of $C$. indica $\mathrm{L}$. on streptozotocin (STZ)-induced diabetic rats during single and repeated administrations to observe acute and chronic effects of the extract on BGLs on diabetic mice.

\section{METHODS}

Sample collection

Fresh leaf of $C$. indica was collected from the vicinity of Varanasi district in Uttar Pradesh, India during the month of January 2018 and air dried. 
The plant material was identified and authenticated by Prof. N. K. Dubey, Taxonomist, Fellow National Academy of Sciences and Fellowship of the National Academy of Agricultural Sciences, Center of Advanced Study in Botany, Institute of Science, Banaras Hindu University, Varanasi, India. The voucher herbarium specimen (Cnna.2018/1) has been deposited in the department of botany.

\section{Preparation of extracts}

Coarsely powdered (200 g) leaf was extracted with 95\% (V/V) alcohol in a Soxhlet apparatus. The extract obtained was filtered and subjected to concentration at a temperature below $50^{\circ} \mathrm{C}$ to obtain a dark brown semi-solid mass. The extract was suspended in distilled water (DW) and used for further studies [14].

\section{Screening of preliminary phytochemical Carbohydrates}

In $2 \mathrm{ml}$ of extract, 2 drops of Molisch's reagent were added and shaken well after that $2 \mathrm{ml}$ of concentrated $\mathrm{H}_{2} \mathrm{SO}_{4}$ was added on the sides of the test tube. A reddish-violet ring appeared at junction of two layers immediately indicate the presence of carbohydrates.

\section{Cholesterol}

In $2 \mathrm{ml}$ of the extract and $2 \mathrm{ml}$ of the chloroform were added in a dry test tube, then 10 drops of acetic anhydride and 2-3 drops of concentrated $\mathrm{H}_{2} \mathrm{SO}_{4}$ were added. A red-rose color changed to bluegreen color.

\section{Proteins}

In $2 \mathrm{ml}$ of protein solution, $1 \mathrm{ml}$ of $40 \% \mathrm{NaOH}$ solution and 1-2 drops of $1 \% \mathrm{CuSO}_{4}$ solution were added. A violet color indicated the presence of peptide linkage of the molecule.

\section{Amino acids}

In $2 \mathrm{ml}$ of extract was added in $2 \mathrm{ml}$ of ninhydrin reagent and kept in water for $20 \mathrm{~min}$. Appearance of purple color indicates the absence of amino acid.

\section{Alkaloids}

The extract was added with $1 \% \mathrm{HCl}, 6$ drops of Mayer's reagent and Dragendorff's reagent. An organic precipitate indicates the presence of alkaloid.

\section{Flavonoids}

In $5 \mathrm{ml}$ of dilute ammonia solution were added to a portion of aqueous filtrate of plant extract followed by addition of concentrated $\mathrm{H}_{2} \mathrm{SO}_{4}$. A yellow coloration is observed, which confirms the presence of flavonoids.

\section{Terpenoids}

In $5 \mathrm{ml}$ of extract was treated with $2 \mathrm{ml}$ of chloroform and $3 \mathrm{ml}$ of concentrated $\mathrm{H}_{2} \mathrm{SO}_{4}$ to form a monolayer of reddish-brown coloration of the interface was showed to from positive result for the terpenoids.

\section{Steroids}

In $2 \mathrm{ml}$ of acetic anhydride was added to $0.5 \mathrm{~g}$ of ethanolic extract of sample with $2 \mathrm{ml}_{\text {of }} \mathrm{H}_{2} \mathrm{SO}_{4}$. The color change from violet to blue or green indicated the presence of steroids.

\section{Tannins}

In $5 \mathrm{ml}$ of extract was added to a few drops of $1 \%$ lead acetate. A yellow precipitate indicated the presence of tannins.

\section{Saponins}

The extract with $20 \mathrm{ml}$ of DW was agitated in a graduated cylinder for $15 \mathrm{~min}$. The formation of $1 \mathrm{~cm}$ layer of form indicated the presence of saponins.

\section{Phlobatannins}

Aqueous extract of plant sample was boiled with $1 \%$ aqueous $\mathrm{HCl}$, red precipitate was deposited which was taken as evidence for the presence of phlobatannins.

\section{Chemicals}

STZ and glibenclamide (DRL, Hyderabad) 2,2-Diphenyl-1-picrylhydrazyl (Sigma Aldrich, Germany), ascorbic acid (S.D. Fine Chemical Limited, India), glucose standard strip/kits, and glucometer. All other chemicals and reagents used are of analytical grade.

\section{Experimental animals}

Experiments were conducted as per Committee for the Purpose of Control and Supervision of Experiments on the Animal guidelines and all animal studies were approved by the Institutional Animal Ethical Committee for animal experimentation 03/BNCP/IAEC/2018, B. N. College of Pharmacy, Udaipur, Rajasthan. Healthy male Swiss albino mice (weighing 20-30 g and age of 8-12 weeks) were taken and kept at the animal breeding house. The animals were kept in polypropylene cage (6-10 animals per cage), under standard laboratory conditions (at room temperature, and with a $12 \mathrm{~h}$ light-dark cycle), and allowed free access to the standard pelleted diet and water ad libitum. Before the initiation of the experiment, the animals were acclimatized to the laboratory conditions for 7 days. All experiments were performed according to animal care and welfare guidelines.

\section{Acute oral toxicity test}

Acute oral toxicity test was performed as per limittestrecommendations of the Organization for Economic Cooperation and Development No. 425 Guideline. Nonpregnant and healthy young adult female Swiss albino mice (age of 8-12 weeks, weighing 20-30 g) were employed for this test. On day 1 , a mouse fasting for $3-4 \mathrm{~h}$ was given $2000 \mathrm{mg} / \mathrm{kg}$ of the extract dissolved in DW orally using oral gavages. The mouse was observed for physical or behavioral changes at least once during the first $30 \mathrm{~min}$, periodically for $24 \mathrm{~h}$, with special attention during the first $4 \mathrm{~h}$. Following the results from the first mouse, the other four mice were recruited and fasted for $3-4 \mathrm{~h}$ and were administered a single dose of $2000 \mathrm{mg} / \mathrm{kg}$ and were observed in the same manner. These observations continued for further 14 days for any signs of overt toxicity [15].

\section{Grouping and dosing of animals}

Swiss albino male mice were used in this study based on previously published reports which revealed that female mice were less sensitive to STZ than males and were also associated with diminished survival rate due to severe induction of diabetes by STZ [16]. Animals were divided randomly into control and treatment groups which comprise six mice in each group. The negative control group received vehicle only, the positive control group received a standard drug glibenclamide $5 \mathrm{mg} / \mathrm{kg}$, and the remaining treatment groups were treated with three different doses $(100,200$, and $400 \mathrm{mg} / \mathrm{kg})$ of leaf extract of $C$. indica $\mathrm{L}$. The doses of the extract were determined based on acute $\mathrm{mg} /$ $\mathrm{kg}$ which was calculated as half of the middle dose. Glibenclamide $5 \mathrm{mg} / \mathrm{kg}$ was selected based on earlier studies. The blood sample was collected from the tail vein of mice. Fasting BGL was determined using a glucometer and each sample was measured in triplicate and then averaged.

\section{Induction of experimental diabetes}

Male Swiss albino mice fasted for 12-14 $\mathrm{h}$ and weights were recorded prior to the induction of diabetes. Experimental diabetes was induced by a single intraperitoneal injection of $150 \mathrm{mg} / \mathrm{kg}$ of STZ, freshly dissolved in $0.1 \mathrm{M}$ citrate buffer $(\mathrm{pH}=4.5)$. Then, the solution was immediately administered intraperitoneally to each mouse. Thirty minutes after the injection, the mice were allowed free access to food and water. After $6 \mathrm{~h} \mathrm{STZ} \mathrm{injection,} \mathrm{mice} \mathrm{were} \mathrm{given} \mathrm{a} \mathrm{5 \%} \mathrm{dextrose} \mathrm{solution} \mathrm{for} \mathrm{the} \mathrm{next}$ $24 \mathrm{~h}$. The development of diabetes was confirmed after 3 days of the STZ injection and mice with fasting BGL $>200 \mathrm{mg} / \mathrm{dl}$ were considered as diabetic and were selected for the experiments [17] 
Hypoglycemic test in normoglycemic mice

Mice fasted for 4-6 h and were then randomly divided into five different groups ( $\mathrm{n}=6$ animals per group). The mice were treated according to their respective grouping. The blood sample was then collected from tail veins of each mouse to determine BGL at $0,1,2,3$, and $4 \mathrm{~h}$ after treatment.

Effect of $C$. indica L. extract on postprandial glycemia in non-diabetic mice

Male mice fasted for 4-6 h and were divided randomly into five groups which comprise six animals each group and baseline BGL was recorded. Thirty minutes after treatment, all mice were loaded with $2 \mathrm{~g} / \mathrm{kg}$ glucose solution [18]. A blood sample was collected from the tail tips of the animals to determine BGL immediately after treatment at 30,60, 120 , and $180 \mathrm{~min}$ following glucose administration.

Antihyperglycemic activity of $C$. indica $\mathrm{L}$. leaf extracts in diabetic mice

After successfully developing the diabetes animals were divided into six groups and each group contains six mice. Group I: Normal control mice administered vehicle only; Group II: Diabetic control mice administered vehicle only; Group III: Tested mice administered glibenclamide $5 \mathrm{mg} / \mathrm{kg}$; and Group IV-VI: Tested mice administered $C$. indica L. at doses of 100,200 , and $400 \mathrm{mg} / \mathrm{kg}$, respectively. All groups received treatments once daily for 14 days. The fasting BGL and body weight were determined at $0,7^{\text {th }}$, and $14^{\text {th }}$ days.

Statistical analysis

All the results were expressed as mean \pm standard error of means for six mice in each group. Statistical analysis was performed using

Table 1: Screening of preliminary phytochemicals of Canna indica $\mathrm{L}$. leaves

\begin{tabular}{llc}
\hline S. no. & Name of the test & Result \\
\hline 1. & Carbohydrates & + \\
2. & Cholesterols & + \\
3. & Proteins & + \\
4. & Amino acids & - \\
5. & Alkaloids & + \\
6. & Flavonoids & + \\
7. & Steroids & + \\
8. & Phlobatannins & + \\
9. & Saponins & + \\
\hline
\end{tabular}

Table 2a: Physicochemical characters of Canna indica L. leaves

\begin{tabular}{ll}
\hline Parameters tested & Percentage yield (\%) \\
\hline Ethanol & 8.0 \\
Methanol & 4.0 \\
Water & 6.0 \\
Loss of wt. on drying & 4.1 \\
Total ash & 17.98 \\
Acid insoluble ash & 69.2 \\
Water-insoluble ash & 48 \\
Alcohol soluble extractive & 3.86 \\
Water-soluble extractive & 6.31 \\
\hline
\end{tabular}

Table 2b: Preliminary phytoprofile for flower of Canna indica L. leaves

\begin{tabular}{lll}
\hline Solvent used & Colors & Consistency \\
\hline Petroleum ether & Light yellow & Non sticky \\
Benzene & Yellow & Non sticky \\
Chloroform & Yellow & Sticky \\
Acetone & Brownish-yellow & Non sticky \\
Methanol & Pale yellow & Non sticky \\
Ethanol & Brown & Non sticky \\
Water & Light brown & Non sticky \\
\hline
\end{tabular}

statistical package for social sciences (SPSS) version 21.0 software. The differences between treated and untreated groups were assessed by one-way analysis of variance followed by Tukey's multiple comparison tests. The result was considered significant when $\mathrm{p}<0.05$.

\section{RESULTS AND DISCUSSION}

Phytochemical screening of $\boldsymbol{C}$. indica $\mathrm{L}$. leaves

The present study carried out the $C$. indica L. leaves revealed the presence of medicinally active metabolite. Qualitative phytochemical analysis of $C$. indica L. leaves confirm the presence of alkaloids, flavonoids, carbohydrates, steroids, proteins, saponins and reported in Table 1.

\section{Physicochemical characters}

Ash usually represent the inorganic part of plant dried powder of C. indica L. leaves was studied for parameter like $\mathrm{pH}$ value (ethanol, methanol and water) loss of weight on drying, total ash, water insoluble ash, acid insoluble ash, water soluble extract and alcohol soluble extractive contents were found to be $8.0 \%, 4.0 \%, 6.0 \%, 4.1 \%$, $17.98 \%, 48 \%, 69.2 \%, 3.86 \%$ and $6.31 \%$ respectively. Result revealed that the acid insoluble ash had maximum percentage and alcohol soluble extractive had minimum percentage. The result are tabulated in Table 2a. The phyto profiling for the extract of $C$. indica $\mathrm{L}$. leaves were tabulated in Table $2 \mathrm{~b}$. The fluorescence analysis of powder and leaves extract of $C$. indica L. were tabulated in Table $3 \mathrm{a}$ and $\mathrm{b}$.

\section{Hypoglycemic test in normoglycemic mice}

The effect of $C$. indica L. on BGL in the normal healthy mice is summarized in Table 4. Pretreatment with GL5 revealed a significant $(\mathrm{p}<0.05$ and $\mathrm{p}<0.001$ ) reduction in BGL starting $1 \mathrm{~h}$ when compared to the negative control. Likewise, the extract also significantly $(\mathrm{p}<0.05, \mathrm{p}<0.01$, and $\mathrm{p}<0.001$ ) reduced the BGL starting $2 \mathrm{~h}$ onward when compared to the negative control group. Intergroup analysis, on the other hand, revealed that the leaf latex extract at a dose of $100 \mathrm{mg} / \mathrm{kg}$ produced significant $(\mathrm{p}<0.001)$ reduction at $2^{\text {nd }}(35.51 \%), 3^{\text {rd }}(39.66 \%)$, and $4^{\text {th }}(42.32 \%)$ in BGL compared to the baseline $(\mathrm{t}=0)$, whereas glibenclamide $(5 \mathrm{mg} / \mathrm{kg})$

Table 3a: Fluorescence analysis of powder of Canna indica L. leaves

\begin{tabular}{lll}
\hline $\begin{array}{l}\text { Particulars of the } \\
\text { treatment }\end{array}$ & Under ordinary light & Under UV light \\
\hline $\begin{array}{l}\text { Powder as such } \\
\text { Powder+1N NaOH } \\
\text { (aqueous) }\end{array}$ & $\begin{array}{l}\text { Brownish-yellow } \\
\text { Brown }\end{array}$ & $\begin{array}{l}\text { Reddish-yellow } \\
\text { Red }\end{array}$ \\
$\begin{array}{l}\text { Powder+1N NaOH } \\
\text { alcoholic) }\end{array}$ & Reddish-yellow & Yellow \\
Powder+1N HCl & Pink & \\
Powder+ $\mathrm{H}_{2} \mathrm{SO}_{4}(1: 1)$ & Orange & Cherry red \\
Powder+HNO $(1: 1)$ & Pale yellow & Greenish-yellow \\
Powder+Ammonia & Pale yellow & Yellow \\
Powder+Iodine & Reddish-brown & $\begin{array}{l}\text { Brick red } \\
\text { Cherry red }\end{array}$ \\
Powder+5\% FeCl & Light green & Yellowish-green \\
Powder+Acetic acid & Brick red & Red \\
\hline UV: Ultraviolet & &
\end{tabular}

Table 3b: Fluorescence characteristic of extract of Canna indica L. leaves

\begin{tabular}{lll}
\hline Extract & $\begin{array}{l}\text { Under ordinary } \\
\text { light }\end{array}$ & $\begin{array}{l}\text { Under UV light } \\
\text { (366 nm) }\end{array}$ \\
\hline Petroleum ether & Light yellow & Green \\
Benzene & Yellow & Green \\
Chloroform & Yellow & Purple-yellow \\
Acetone & Brownish-yellow & Cherry red \\
Methanol & Pale yellow & Light green \\
Water & Light brown & Purple \\
\hline
\end{tabular}


Table 4: Effect of leaf extract of Canna indica L. on BGL of normoglycemic mice

\begin{tabular}{|c|c|c|c|c|c|}
\hline \multirow[t]{2}{*}{ Group } & \multicolumn{5}{|c|}{ Blood glucose (mg/dl) level in different time intervals (hours) } \\
\hline & $\mathbf{0} \mathbf{h}$ & $1 \mathrm{~h}$ & $2 \mathrm{~h}$ & $3 \mathbf{h}$ & $4 \mathrm{~h}$ \\
\hline DW10 & $122.00 \pm 1.93$ & $121.33 \pm 4.42$ & $119.73 \pm 6.50$ & $122.50 \pm 7.74$ & $125.33 \pm 10.05$ \\
\hline CI100 & $118.44 \pm 2.11$ & $104.17 \pm 8.06$ & $76.95 \pm 5.181$ & $72.00 \pm 5.162$ & $67.84 \pm 7.682$ \\
\hline CI200 & $111.67 \pm 4.34$ & $89.00 \pm 10.48$ & $85.84 \pm 9.021$ & $76.44 \pm 10.941$ & $67.67 \pm 9.742$ \\
\hline CI400 & $115.84 \pm 4.60$ & $86.28 \pm 12.72$ & $72.95 \pm 9.712$ & $66.67 \pm 7.504$ & $65.72 \pm 8.75$ \\
\hline
\end{tabular}

CI200: Canna indica L. extract $200 \mathrm{mg} / \mathrm{kg}$, CI400: Canna indica L. extract $400 \mathrm{mg} / \mathrm{kg}, 1$ p<0.05, 2 p<0.01, 3 p<0.001. BGL: Blood glucose level

Table 5: Effect of leaf extract of Canna indica L. on postprandial glycemia in nondiabetic mice

\begin{tabular}{|c|c|c|c|c|c|}
\hline \multirow[t]{2}{*}{ Group } & \multicolumn{5}{|c|}{ Blood glucose $(\mathrm{mg} / \mathrm{dl})$ level in different time intervals } \\
\hline & $\mathbf{0} \min$ & $30 \mathrm{~min}$ & $60 \mathrm{~min}$ & $120 \mathrm{~min}$ & $180 \mathrm{~min}$ \\
\hline DW10 & $104.67 \pm 4.49$ & $182.44 \pm 9.16$ & $156.17 \pm 6.911$ & $111.00 \pm 4.764$ & $100.84 \pm 4.604$ \\
\hline GL5 & $97.67 \pm 1.86$ & $124.56 \pm 7.82$ & $78.50 \pm 2.603$ & $68.67 \pm 2.432$ & $62.67 \pm 2.44$ \\
\hline CI100 & $98.33 \pm 3.69$ & $134.66 \pm 15.98$ & $63.16 \pm 6.553$ & $60.66 \pm 8.452$ & $68.68 \pm 6.69$ \\
\hline CI200 & $102.17 \pm 2.99$ & $162.86 \pm 16.96$ & $66.17 \pm 9.296$ & $56.95 \pm 7.656$ & $66.00 \pm 4.29$ \\
\hline CI400 & $101.00 \pm 2.74$ & $170.17 \pm 11.08$ & $84.86 \pm 6.996$ & $74.61 \pm 10.401$ & $70.00 \pm 4.21$ \\
\hline
\end{tabular}

Results are expressed in mean \pm standard error of the mean, n=6, DW10: Distilled water $10 \mathrm{ml} / \mathrm{kg}$; GL5: Glibenclamide $5 \mathrm{mg} / \mathrm{kg}$, CI100: Canna indica L. extract 100 mg/kg, CI200: Canna indica L. extract $200 \mathrm{mg} / \mathrm{kg}$, CI400: Canna indica L. extract $400 \mathrm{mg} / \mathrm{kg}, 1$ p <0.05, 2 p<0.01, 3 p<0.001

showed significant $(\mathrm{p}<0.001)$ reduction in BGL at $1^{\text {st }}(38.42 \%), 2^{\text {nd }}$ $(48.85 \%), 3^{\text {rd }}(52.25 \%)$, and $4^{\text {th }}(57.49 \%)$ compared to the baseline $(\mathrm{t}=0)$. By contrast, DW10 does not produce any significant reduction in BGL across all time points compared to the baseline $(\mathrm{t}=0)$.

The effect of $C$. indica $L$. extract on postprandial glycemia in nondiabetic mice

Administration of glucose $(2 \mathrm{~g} / \mathrm{kg})$ to the mice produced significant $(\mathrm{p}<0.001)$ increase in BGL 30 min following $1 \mathrm{~h}$ after glucose loading, confirming the induction of hyperglycemia. The extract with three doses $(100,200$, and $400 \mathrm{mg} / \mathrm{kg})$ showed a significant reduction in BGL from 60 min onward when compared to the control group. By contrast, mice treated with GL5 showed a significant reduction in BGL starting from $30 \mathrm{~min}$ onward compared to the negative control group. Furthermore, no apparent difference was noted when the different doses of the extract were compared with each other as well as with the positive control at all-time points (Table 5).

Antihyperglycemic activity of $C$. indica L. in STZ-induced diabetic mice

STZ-induced diabetic mice showed significant $(\mathrm{p}<0.001)$ differences in BGL compared to normal control. Treatment with all doses of the leaf latex extract showed significant $(\mathrm{p}<0.05$ and $\mathrm{p}<0.001)$ reduction in the BGL at the 7th and 14th days, respectively, compared to diabetic control. Similarly, GL5 treated group revealed significant $(\mathrm{p}<0.001)$ reduction in BGL at the $7^{\text {th }}$ and $14^{\text {th }}$ days. Within-group analysis indicated that treatment with CI100, CI200, and GL5 resulted in a significant reduction in BGL at the $7^{\text {th }}$ day. By contrast, CI400 failed to show a reduction of BGL at the $7^{\text {th }}$ day. The maximum reduction in fasting BGL was attained at the $14^{\text {th }}$ day, $23.18 \%, 22.2 \%, 23.91 \%$, and $25.22 \%$, respectively, for CI100, CI200, CI400, and GL5 (Table 6).

Effect of the leaf extract of $C$. indica $L$. on body weight

The effects of the leaf extract on body weight in diabetic mice are shown in Table 7. All groups before extract administration (0 day) showed no apparent difference in body weight compared to the normal control group. Significant body weight gain was recorded for CI200 ( $<<0.05)$, CI400 ( $<<0.01)$, and GL5 ( $p<0.05)$ at the $7^{\text {th }}$ day of treatment compared to the diabetic control group. All doses of the extract and GL5 showed a significant $(\mathrm{p}<0.001)$ improvement in body weight at the $14^{\text {th }}$ day when compared to diabetic control. By contrast, the body weight of the diabetic control group was significantly decreased $(\mathrm{p}<0.01)$ at the $14^{\text {th }}$ day compared to a normal control group.
Table 6: Effect of leaf extract of Canna indica L. in STZ-induced diabetic mice

\begin{tabular}{llll}
\hline Group & \multicolumn{3}{l}{ Blood glucose level in $\mathbf{~ m g} / \mathbf{d L}$} \\
\cline { 2 - 4 } & Day 0 & Day 7 & Day $\mathbf{1 4}$ \\
\hline NC & $102.66 \pm 4.076$ & $98.86 \pm 6.206$ & $101.66 \pm 6.886$ \\
DC & $262.33 \pm 4.48$ & $264.83 \pm 1.18$ & $266.83 \pm 5.25$ \\
GL5 & $255.36 \pm 2.63$ & $221.50 \pm 3.283$ & $192.67 \pm 2.58$ \\
CI100 & $264.37 \pm 6.63$ & $240.50 \pm 4.553$ & $202.72 \pm 2.36$ \\
CI200 & $261.17 \pm 4.29$ & $238.50 \pm 7.101$ & $203.00 \pm 1.96$ \\
CI400 & $264.50 \pm 7.26$ & $240.17 \pm 5.742$ & $201.00 \pm 2.86$ \\
\hline
\end{tabular}

Results are expressed in mean \pm standard error of the mean, $n=6, \mathrm{NC}$ : Normal control, DC: Diabetic control, GL5: Glibenclamide $5 \mathrm{mg} / \mathrm{kg}$, CI100: Canna indica L. extract 100 mg/kg, CI200: Canna indica L. extract $200 \mathrm{mg} / \mathrm{kg}$, CI400: Canna indica L. extract $400 \mathrm{mg} / \mathrm{kg}, 1 \mathrm{p}<0.05,2 \mathrm{p}<0.01,3 \mathrm{p}<0.001$. STZ: Streptozotocin

Table 7: Effect of leaf extract of Canna indica $\mathrm{L}$. on body weight in diabetic mice

\begin{tabular}{llll}
\hline Group & \multicolumn{3}{l}{ Body weight in gram } \\
\cline { 2 - 4 } & Day 0 & Day 7 & Day 14 \\
\hline NC & $27.02 \pm 0.86$ & $27.83 \pm 0.68$ & $27.25 \pm 0.92$ \\
DC & $25.65 \pm 0.94$ & $24.83 \pm 1.23$ & $23.83 \pm 0.97$ \\
GL5 & $25.97 \pm 0.71$ & $29.88 \pm 0.551$ & $30.63 \pm 0.51$ \\
CI100 & $24.50 \pm 1.06$ & $26.54 \pm 0.68$ & $28.03 \pm 0.92$ \\
CI200 & $24.33 \pm 0.68$ & $28.04 \pm 0.702$ & $28.89 \pm 0.76$ \\
CI400 & $25.17 \pm 0.83$ & $29.72 \pm 0.223$ & $30.21 \pm 0.42$ \\
\hline
\end{tabular}

Results are expressed in mean \pm standard error of the mean, $n=6$, NC: Normal control, DC: Diabetic control, GL5: Glibenclamide $5 \mathrm{mg} / \mathrm{kg}$, CI100: Canna indica L. extract $100 \mathrm{mg} / \mathrm{kg}$, CI200: Canna indica L. extract $200 \mathrm{mg} / \mathrm{kg}, \mathrm{CI} 400$ : Canna indica L. extract $400 \mathrm{mg} / \mathrm{kg} ; 1$ p $<0.05,2$ p $<0.01,3$ p $<0.001$

\section{CONCLUSION}

The present study, preliminary phytochemical and physicochemical evaluation of $C$. indica $\mathrm{L}$. leaves could be used as the diagnostic tool for the standardization of medicinal plant. It can be considered as the identifying parameters to substantiate and authenticate the drug. The present findings also established that the leaf extract of $C$. indica $\mathrm{L}$. is capable of exhibiting significant antihyperglycemic activities in STZ-induced diabetic mice. The plant also showed improvement in parameters such as oral glucose tolerance, body weight, and hypoglycemic activity. The results give scientific support for the use of the plant in folk medicine for 
the management of diabetes and its associated complications. C. indica $\mathrm{L}$. would be promising for further clinical studies in the management of DM. Further studies to find out the mechanism of this plant for its antidiabetogenic effect and to identify the bioactive compounds responsible for this effect are necessary.

\section{ACKNOWLEDGMENTS}

The author would like to express heartily thanks to DRL, Hyderabad, for providing STZ and glibenclamide as a free gift samples and also thanks to B.N. Institute of Pharmaceutical Sciences, B.N. University for providing the research facility.

\section{AUTHORS' CONTRIBUTIONS}

Dr. S. S. Sisodia constructed an idea for the manuscript and planned methodology to reach the conclusion. Mr. Prashant Kumar Yadav was taken responsibility in execution of the experiments, data management, reporting, and presentation of the results. Mr. Prashant Kumar Yadav organized the manuscript and Dr. S.S. Sisodia supervised the manuscript preparation and reviewed the manuscript.

\section{CONFLICTS OF INTEREST}

The authors declare that they have no conflicts of interest, financial, or otherwise.

\section{REFERENCES}

1. Dhodi JB, Mestry SN, Juvekar AR. Diabetic nephropathy: Genesis, prevention and treatment. Int J Pharm Pharm Sci 2014;6:42-7.

2. Kumar KE, Jyotsna PD, Ram KR, Swathi P, Gupta MN. Parmacodynamic and pharmacokinetic drug interaction of gliclazide and risperidone in animal models. Int J Pharm Pharm Sci 2012;4:659-62.

3. Kishore L, Kaur N, Singh R. Distinct biomarkers for early diagnosis of diabetic nephropathy. Curr Diabetes Rev 2017;13:598-605.
4. Kim Y, Park CW. New therapeutic agents in diabetic nephropathy. Korean J Int Med 2017;32:11-25.

5. Acharya VN. Diabetic and hypertensive nephropathy in India. J Assoc Physicians India 2011;59:143.

6. Pradeepa R, Mohan V. Prevalence of Type 2 diabetes and its complications in India and economic costs to the nation. Eur J Clin Nutr 2017;71:816-24.

7. Bener A, Al-Laftah F, Al-Hamaq AO, Daghash M, Abdullatef WK. A study of diabetes complications in an endogamous population: An emerging public health burden. Diabetes Metab Syndr 2014;8:108-14.

8. Tripathi SM, Singh DK. Molluscicidal activity of Punica granatum bark and Canna indica root. Braz J Med Biol Res 2000;33:1351-5.

9. Jamal P, Barkat AA, Amid A. Distribution of phenolics in various Malaysian medicinal plants. J Appl Sci 2010;10:2658-62.

10. Indrayan AK, Bhojak NK, Kumar N, Shatru A, Gaur A. Chemical composition and antimicrobial activity of the essential oil from the rhizome of Canna indica Linn. Indian J Chem B Org Med Chem 2011;50B:1136-9.

11. Joshi YM, Kadam VJ, Kaldhone PR. Antioxidant activity of methanolic extract of aerial parts of Canna indica L. J Pharm Res 2009;2:1712-5.

12. Nirmal SA, Shelke SM, Gagare PB, Jadhav PR, Dethe PM. Antinociceptive and anthelmintic activity of Canna indica. Nat Prod Res 2007;21:1042-7.

13. Prakash SL, Kumar AK. Antioxidant activity and wound healing potential of selected medicinal plants. J Chem Pharm Sci 2014;2:100-4.

14. Gupta A, Naraniwal M, Kothari V. Modern extraction methods for preparation of bioactive plant extracts. Int J Appl Nat Sci 2012;1:8-26.

15. OECD/OECDE, Test No. 407: Repeated Dose 28 day Oral Toxicity Study in Rodents; 2008.

16. Fröde TS, Medeiros YS. Animal models to test drugs with potential antidiabetic activity. J Ethnopharmacol 2008;115:173-83.

17. Mustaffa F, Indurkar J, Shojai MS. A review of Malaysian medicinal plants with potential antidiabetic activity. J Pharm Res 2011;4:4217-24.

18. Hammeso WW, Emiru YK, Getahun KA, Kahaliw W. Antidiabetic and antihyperlipidemic activities of the leaf latex extract of Aloe megalacantha baker (Aloaceae) in streptozotocin-induced diabetic model. Evid Based Complement Alternat Med 2019;2019:1-9. 